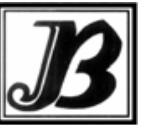

J. bio-sci. 19: 43-52, 2011

ISSN 1023-8654

http://www.banglajol.info/index.php/JBS/index

\title{
YIELD RESPONSE OF DIALLELIC CROSSED MAIZE (ZEA MAYS L.) GENOTYPES TO VARYING NITROGEN REGIMES IN NIGERIA
}

\author{
OB Bello*, MS Afolabi ${ }^{\ddagger}$, SA Ige ${ }^{2}$, SY Abdulmaliq ${ }^{3}$, MA Azeez $^{4}, \mathrm{~J} \mathrm{Mahmud}^{5}$ \\ Department of Biological Sciences, Fountain University, Osogbo, Osun State, Nigeria \\ ${ }^{1}$ Department of Crop Science, Landmark University, Omuaran, Kwara State, Nigeria \\ 2Department of Agronomy, University of Ilorin, Ilorin, Nigeria \\ ${ }^{3}$ Department of Agronomy, Ibrahim Badamasi Babangida University, Lapai, Niger State, Nigeria \\ ${ }^{4}$ Department of Plant Biology, Ladoke Akintola University of Technology, Ogbomoso, Nigeria \\ ${ }^{5}$ Lower Niger River Basin, llorin, Kwara State, Nigeria
}

\begin{abstract}
Context: Development of early maturing maize cultivars that remain productive under low $\mathrm{N}$ fertilizer farming system, consistent with the farmers' technologies is a prerequisite to improving adoption of new varieties without increasing production cost.

Objective: To assess the performance of ten early open pollination maize varieties (OPVs) and their $F_{1}$ hybrids for grain yield and nitrogen use efficiency (NUE), and also identify productive cultivars under low $\mathrm{N}$ fertilizer regimes.

Materials and Methods: The trials were set up in a split plot arrangement with three $\mathrm{N}$ fertilizer levels $(0,45$ and 90 $\mathrm{kg} \mathrm{N} \mathrm{ha}^{-1}$ ) as main plot and the genotypes as sub-plot. Each plot within $\mathrm{N}$ level was four-row, laid out in a randomized complete block design of four replications. Ten OPVs were crossed in a half diallel to generate $45 \mathrm{~F}_{1}$ hybrids during 2004 and 2005 growing seasons. Planting were carried out on 20 th July, 2005 and $2^{\text {nd }}$ July, 2006. Agronomic characters studied were grain yield, maize establishment count, days to $50 \%$ tasselling and silking as well as plant and ear heights.

Results: The year 2005 growing season was better for all observed characters amongst all the genotypes than the year 2006. Although, expressions of these traits in the hybrids were relatively higher than the OPVs including the grain yield. The total increase in grain yield observed was $1.72 \mathrm{t}$ ha- ${ }^{-1}$ and $1.95 \mathrm{t} \mathrm{ha-}{ }^{-1}$ for OPVs and hybrids respectively on application of $90 \mathrm{~kg}$ ha-1 over no $\mathrm{N}$-application. However, NUE was optimum at $45 \mathrm{~kg} \mathrm{~N}^{-1} \mathrm{H}^{-1}$ in both groups. Grain yield and NUE correlated positively with growth characters measured except for days to $50 \%$ silking Higher genetic gains were recorded for plant and ear heights.
\end{abstract}

Conclusion: Two drought tolerant varieties (Acr 90 Pool 16-Dt and Tze Comp3 Dt) that combined well with specific cultivars for grain yield and NUE probably have gene pools for low $\mathrm{N}$-tolerance.

Keywords: Nitrogen use efficiency, diallel crosses, maize cultivars, open pollinated varieties

\section{Introduction}

Maize (Zea mays L.) is an important staple food crops and provides both bulks of raw materials for the livestock and many agro-allied industries in the world (Bello et al. 2010, Undie et al. 2012). Maize has a wide range of uses than any other cereals because of its world-wide distribution, high yielding nature, ease of processing, readily digestible and relatively lower price of the grain. In recent times, importance of maize production has been widely publisized among farmers of Nigeria. The soils however, are fragile, primarily of kaolinitic Alfisols with low organic matter, effective cation exchange capacity and plant nutrients (Carsky and Iwuafor 1999) creates low yield problems in this agro-climate conditions. The attendant problems of the soils frequently deficient in nitrogen $(\mathrm{N})$ due to high rate of leaching, denitrification, decomposition of organic matter and erosive action of rainfall had not only made nitrogen the most limiting nutrient to maize production in Nigeria (Carsky and Iwuafor 1999, Yusuf et al. 2003) but also enhance low soil moisture retention. Despite the soil being low in plant available nutrients, $\mathrm{N}$ deficiency is further exacerbated from its continual depletion 
from the soil pool by removal of $\mathrm{N}$-containing crop residues from the farm. Nitrogen depletion in maize-based systems in some farmer's fields in West African savannah is estimated to be $36-80 \mathrm{~kg} \mathrm{~N}^{-1}{ }^{-1}$ per year (Sanginga et al. 2001). In view of the fact that farmers hardly adopt option that could provide supplemental $\mathrm{N}$ to maize crops (perhaps manuring, mulching, crop rotation and fallowing schemes), the knock-out effect is that maize production by small holder farmers is normally at a lower capacity (with decrease in the total maize yield) and at a subsistence level solely to meet family consumption. Despite fertilizers recommendations ( 60 to $120 \mathrm{~kg} \mathrm{~N} \mathrm{ha}^{-1}$ ) for resource poor farmers in the West Africa moist savannah (Carsky and Iwuafor 1999), less than $20 \mathrm{~kg} \mathrm{~N}^{-1}$ used in Nigeria was considered grossly inadequate and $50 \mathrm{~kg}$ nutrient ha-1 fertilizer use was recommended across sub-Saharan Africa by African Heads of States at the Fertilizer Summit held in 2006 at Abuja, Nigeria (Yusuf et al. 2009).

The southern Guinea savannah (SGS) of Nigeria has great potential for the expansion of maize production beyond the present level due to its bimodal rainfall pattern, high solar radiation and favourable temperature during the growing season. However, the zone is mitigated with problems such as erratic nature of rainfall pattern, low soil nutrient status and water holding capacity due to fragility of the soil that consistently prone to drought (Fakorede et al. 2001, Bello 2008). Hybrid maize is well known in the region for its high demand for plant nutrients and other production inputs. The farmers have been indoctrinated with the belief that required amount of inorganic fertilizers need to be applied for maximum performance of hybrid maize and good economic returns. This extra production cost discourages most farmers engaging in hybrid maize production in the country (Kogbe and Adediran 2003). However, as a result of increasing cost of $\mathrm{N}$ fertilizer due to reduction in government subsidy, poor infrastructure for production and distribution, resulted to inadequate or untimely supply of fertilizers to farmers. Lack of cash or access to credit and perception of cost-benefit ratio also made $\mathrm{N}$ fertilizers sometimes unavailable or are too expensive and often beyond the reach of resource poor farmers who constitute the bulk of maize growers in the moist savannah of West Africa (Juo and Mano 1996). Maize cultivars that are productive under conditions of low N availability are therefore highly desirable.

In the development of improved maize productivity in a sustainable fashion in areas with low $\mathrm{N}$ fertility, two basic approaches can be taken. The first, approach is to develop innovative agronomic practices that efficiently utilized $\mathrm{N}$ from organic matter and $\mathrm{N}$ inputs from biological fixation and atmospheric deposition. The second approach is to work with population with the reservoir of genes for low $\mathrm{N}$ tolerance (Smith et al. 1994). One strategy for improving the productivity of maize under sub-optimal $\mathrm{N}$ fertility is to use the second approach. The low $\mathrm{N}$ tolerance cultivars are superior in the utilization of available $\mathrm{N}$, either due to enhanced $\mathrm{N}$ - uptake capacity or because of more efficient use of absorbed $\mathrm{N}$ for grain production (Lafitte and Edmeades 1994). On the other hand, combination with the first approach will lead to high maize yields. Evaluation of open pollination maize varieties (OPVs) and their $F_{1}$ hybrids in a diallel cross however could provide a worthwhile knowledge on those genotypes that could be used either directly for cultivation or for extraction of inbred lines for low $\mathrm{N}$ tolerant hybrid development. A corollary is that these genotypes can readily fit into environment with erratic rainfall and low water holding capacity, since they are bred for marginal environments of West and Central Africa. Thus, development of early maturing maize cultivars that remain productive under low $\mathrm{N}$ fertilizer farming system, consistent with the farmers' technologies is therefore a prerequisite to improving adoption of new varieties without increasing production cost in this agro-ecology. The objectives of this research therefore was to assess the performance of ten early OPVs and their $F_{1}$ hybrids under low $\mathrm{N}$ fertilizer regimes with the view to identify those that could be cultivated either as varieties per se under the farmer's practices or those that could be introgressed with other released cultivars to develop low N-tolerant varieties in the SGS ecology of Nigeria. 


\section{Materials and Methods}

Field experiments were conducted at the Teaching and Research farm of the University of llorin (Latitude $80^{\circ}$ $29^{\prime} \mathrm{N}$, Longitude $40^{\circ} 35^{\prime} \mathrm{E}$ and annual rainfall of $945 \mathrm{~mm}$ ) in the SGS of Nigeria. The soil is classified as Typic paleustalf (United State Department of Agriculture, USDA soil taxonomy). Composite soil samples were collected randomly from the trial site at the depth of $0-15 \mathrm{~cm}$ with an auger prior to planting in 2005 and 2006 respectively. The samples were transferred to the laboratory for physico-chemical analysis. The collected samples were air-dried and passed through $2 \mathrm{~mm}$ sieve to remove large particles, debris and stones. The sieved samples were analyzed for $\mathrm{pH}$ in 1:1 soil to water ratio using the Coleman's $\mathrm{pH}$ meter. Organic carbon was determined by Walkley and Black procedure (Nelson and Somers 1992). Total Nitrogen was determined by the micro Kjeldahl method (Bremner 1965), while available phosphorus was extracted by Bray's P1 method (Bray and Kurtz 1945) and read by the Atomic Absorption Spectrometer. Potassium was evaluated calorimetrically using molybdenum blue. Calcium and magnesium were estimated by Versenate ethylenediaminetetraacetic acid (EDTA) titration method (Juo 1979), while exchangeable potassium and sodium were analyzed using flame photometry (Juo 1979). The exchangeable cations were measured on extracts obtained after leaching soil samples with neutral normal ammonium acetate solution (IITA, 1979). Rainfall distribution data for the year 2005 and 2006 were also collected at the Lower Niger River Basin Development Authority, llorin, Nigeria.

The genetic materials used were ten OPVs of maize, selected for grain yield and adaptation to abiotic (drought) and biotic (stalk rot, striga and downy mildew) stress factors. They were early to medium maturing white cultivars with maturity period of 90 to 100 days. The cultivars were obtained from the International Institute of Tropical Agriculture (IITA), Ibadan. The origin, characteristic features and ecological adaptation of ten open pollinated maize varieties are shown in Table 1. The ten varieties were crossed in a half diallel to generate $45 F_{1}$ hybrids during 2004 and 2005 cropping seasons. Planting were carried out during the growing seasons on 20th July, 2005 in the first year and 2nd July, 2006 in the second year. The resultant hybrids were harvested, processed and stored in the cold room prior to field evaluation.

It is worthwhile to mention that the ultimate goal is not diallel analysis in which using pure lines as parents is necessary. The trials were set up in a split plot arrangement with $\mathrm{N}$-level as main plot and the genotypes as sub-plot. Each plot within $\mathrm{N}$ level was four-row, laid out in a randomized complete block design (RCBD) of four replications at spacing of $0.75 \mathrm{~m}$ between and $0.50 \mathrm{~m}$ within the rows. Each hill was planted to three seeds but was later thinned to two plants per hill to give a plant population of approximately 53,333 per hectare. Plantings were done on $28^{\text {th }}$ July in 2005 and $22^{\text {nd }}$ July in 2006. Nitrogen fertilizer in form of granular

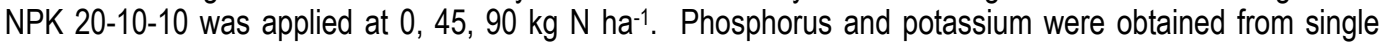
super phosphate (SSP) and murate of potash (MOP) respectively. The required quantities for each level of $\mathrm{N}$ were computed from the three combinations. All the SSP and MOP fertilizers were applied once at planting which included $60 \%$ of the NPK. The remaining $40 \%$ was applied at 6 weeks after planting (WAP). The fertilizers were applied by spot placement.

Data were collected from the two middle rows in each plot. Agronomic parameters recorded in each cropping seasons were seedling establishment count; plants and ear heights were measured as the distance from the ground level to the flag leaf and the node bearing the uppermost ear respectively using measuring tape. Days to $50 \%$ tasselling and silking were taken as the date when $50 \%$ of the plants in a plot had tasselled and extrude silk respectively. Anthesis-silking interval was estimated as the difference between days to pollen shed and silking. Moisture at harvest was determined by collection of 500 grain samples from each plot. The samples were first weighed to obtain initial weight, followed by drying to a constant weight in the oven at $80^{\circ} \mathrm{C}$, and the difference between the two weights were recorded as the moisture at harvest. Grain yield was obtained from ear weight per plot (assuming $80 \%$ shelling percentage) and converted to tonnes per hectare after adjusting to $12 \%$ moisture content. Nitrogen use efficiency (NUE) was estimated as grain yield per unit of available soil $\mathrm{N}$ as NUE $=\frac{\text { Grain yield (g/plant) at } \mathrm{N} \text { rata applied-grain yield at o } \mathrm{kg}_{\mathrm{g}} \mathrm{ha}^{-1}}{\mathrm{~N} \text { applied (gNf) }}$, where gNf $=$ amount of $\mathrm{N}$ applied. 
The data were subjected to analysis of variance and pertinent means were separated using Least Significant Difference (LSD) according to Gomez and Gomez (1984). The phenotypic, genotypic and environmental correlation coefficients were estimated from the mean squares and mean across products as suggested by Mode and Robinson (1959). Genstat Statistical Package (Genstat 1995) was used to compute simple linear correlation. Analysis of variance (ANOVA) on individual site basis was first computed before a combined ANOVA across sites.

Table 1. Origin, genetic background, breeding emphasis and ecological adaptation of the maize parent

\begin{tabular}{|c|c|c|c|}
\hline Genotypes & Origin and genetic background & $\begin{array}{l}\text { Breeding } \\
\text { emphasis }\end{array}$ & $\begin{array}{l}\text { Ecological } \\
\text { adaptation }\end{array}$ \\
\hline Acr 90 Pool 16-Dt & $\begin{array}{l}\text { Early white dent CIMMYT cultivar, derived from crosses among } \\
\text { large numbers of early late white flint materials from Mexico, the } \\
\text { Caribbean area, Central and South America. Selected for } \\
\text { drought tolerance. }\end{array}$ & $\begin{array}{l}\text { Stalk rot, Striga } \\
\text { and drought } \\
\text { tolerance. }\end{array}$ & $\begin{array}{l}\text { Forest and } \\
\text { savannah. }\end{array}$ \\
\hline Tze Comp 4-Dmr Srbc2 & $\begin{array}{l}\text { Early maturing white and semi dent cultivar, derived from } \\
\text { diverse sources of early mid-altitude germplasm, intermatted } \\
\text { with TZESR-W and DMR-ESRW. }\end{array}$ & $\begin{array}{l}\text { Yield and Striga } \\
\text { tolerance. }\end{array}$ & $\begin{array}{l}\text { Forest and } \\
\text { savannah. }\end{array}$ \\
\hline Tze Comp4 C2 & $\begin{array}{l}\text { Early maturing white and semi dent cultivar, derived from } \\
\text { diverse sources of early mid-altitude germplasm, intermatted } \\
\text { with EV } 8430-S R \text { and IK } 8149 \text { SR. It has synchronous male and } \\
\text { female flowering, lower plant height and small tassel size. }\end{array}$ & $\begin{array}{l}\text { Yield and Striga } \\
\text { tolerance. }\end{array}$ & $\begin{array}{l}\text { Forest and } \\
\text { savannah. }\end{array}$ \\
\hline Acr 97 Tze Comp3 C4 & $\begin{array}{l}\text { Early white flint dent cultivar, derived from early mid-altitude } \\
\text { germplasm with EV 8430-SR, DMR-ESRW, TZESR-W and IK } \\
8149 \text { SR intermatted. }\end{array}$ & $\begin{array}{l}\text { Yield, downy } \\
\text { mildew and Striga } \\
\text { tolerance. }\end{array}$ & $\begin{array}{l}\text { Forest and } \\
\text { savannah. }\end{array}$ \\
\hline Hei 97 Tze Comp3 C4 & $\begin{array}{l}\text { Early white flint dent cultivar, derived from early mid-altitude } \\
\text { germplasm with EV 8430-SR, DMR-ESRW, TZESR-W and IK } \\
8149 \text { SR intermatted. }\end{array}$ & $\begin{array}{l}\text { Yield, downy } \\
\text { mildew and Striga } \\
\text { tolerance. }\end{array}$ & $\begin{array}{l}\text { Forest and } \\
\text { savannah. }\end{array}$ \\
\hline Acr 94 Tze Comp5 & $\begin{array}{l}\text { Early white flint dent cultivar, derived from early mid-altitude } \\
\text { germplasm with Striga intermatted with TZE-WC3. }\end{array}$ & Striga tolerance. & Savannah. \\
\hline Tze Comp3 Dt & $\begin{array}{l}\text { Early white flint dent cultivar, derived from diverse sources of } \\
\text { early mid-altitude germplasm with drought tolerant cultivars, } \\
\text { intermatted with TZESR-W and DMR-ESRW. }\end{array}$ & $\begin{array}{l}\text { Drought } \\
\text { tolerance. }\end{array}$ & $\begin{array}{l}\text { Forest and } \\
\text { savannah }\end{array}$ \\
\hline Tze Comp3 C2 & $\begin{array}{l}\text { Early white and flint dent cultivar, derived from diverse sources } \\
\text { of early mid-altitude germplasm, produced by intermating } \\
\text { TZESR-W and DMR-ESRW. }\end{array}$ & $\begin{array}{l}\text { Downy mildew } \\
\text { and Striga } \\
\text { tolerance. }\end{array}$ & $\begin{array}{l}\text { Forest and } \\
\text { savannah. }\end{array}$ \\
\hline Ak 95 Dmr-Esrw & $\begin{array}{l}\text { Early maturing and flint dent cultivar, developed from } \\
\text { intermating diverse sources of early mid-altitude germplasm, } \\
\text { produced by intermating DMR sources from Philippines with } \\
\text { TZB, TZBP, TZSR and tropical late. Selected for earliness. }\end{array}$ & $\begin{array}{l}\text { Downy mildew } \\
\text { and Striga } \\
\text { tolerance. }\end{array}$ & Forest. \\
\hline Tze Msr-W & $\begin{array}{l}\text { Early white semi dent cultivar, derived from early mid-altitude } \\
\text { germplasm, developed from intermating local and early cultivars } \\
\text { with TZSR. }\end{array}$ & $\begin{array}{l}\text { Yield and Striga } \\
\text { tolerance. }\end{array}$ & $\begin{array}{l}\text { Forest and } \\
\text { savannah. }\end{array}$ \\
\hline
\end{tabular}

Source: IITA Archival Report 1988-1992

\section{Results}

Soil Analysis: Soil samples were collected from the trial site before cropping in 2005 and 2006 were analyzed in the laboratory for selected physical and chemical properties (Table 2). The soil texture was loamy sand with similar values of soil properties in both years. The soil had a pH of 5.4 which is moderately acidic. The soil organic matter and total nitrogen was low, while the soil available Phosphate and the exchangeable cations $(\mathrm{K}, \mathrm{Na}, \mathrm{Ca}$ and $\mathrm{Mg})$ were moderate for maize production in this area. However, rainfall distribution data for the year 2009 and 2010 were also collected (Fig. 1). 
Table 2. Selected physical and chemical characteristics of the soil before growing maize in 2005 and 2006 .

\begin{tabular}{lcc}
\hline Physical characteristics & 2005 & 2006 \\
Texture & Loamy sand & Loamy sand \\
$\mathrm{pH} 1: 1\left(\mathrm{H}_{2} \mathrm{O}\right)$ & 5.4 & 5.30 \\
Sand \% & 84.1 & 84.0 \\
Clay \% & 8.02 & 8.01 \\
Silt \% & 6.42 & 6.40 \\
Chemical characteristics & & \\
Exchangeable $\mathrm{Ca}^{2+}\left(\mathrm{C} . \mathrm{mol} \mathrm{kg}^{-1}\right)$ & 1.12 & 1.10 \\
Exchangeable $\mathrm{Mg}^{2+}\left(\mathrm{C} . \mathrm{mol} \mathrm{kg}^{-1}\right)$ & 1.62 & 1.61 \\
Exchangeable $\mathrm{Na}^{+}\left(\mathrm{C} . \mathrm{mol} \mathrm{kg}^{-1}\right)$ & 0.19 & 0.18 \\
Exchangeable $\mathrm{K}^{+}\left(\mathrm{C} . \mathrm{mol} \mathrm{kg}^{-1}\right)$ & 0.01 & 0.01 \\
Total acidity $\mathrm{H}^{+}\left(\mathrm{C} . \mathrm{mol} \mathrm{kg}^{-1}\right)$ & 0.05 & 0.04 \\
Cation exch. Cap. $\left(\mathrm{C} . \mathrm{mol} \mathrm{kg}^{-1}\right)$ & 2.83 & 2.82 \\
$\%$ Organic Carbon & 0.24 & 0.26 \\
$\%$ Soil organic matter & 1.03 & 1.04 \\
$\%$ Total Nitrogen & 0.24 & 0.26 \\
Available Phosphate $\left(\mathrm{mg} \mathrm{kg}^{-1}\right)$ & 20.31 & 20.30 \\
\hline
\end{tabular}

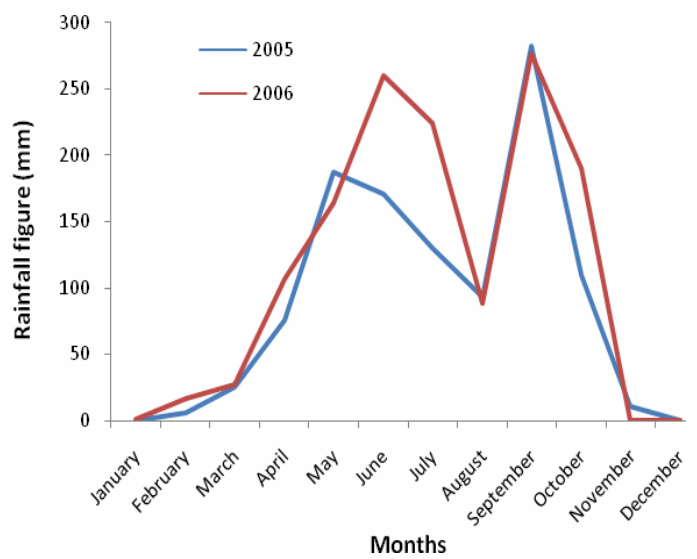

Fig. 1. Rainfall distribution pattern for llorin in 2005 and 2006

Table 3. Maize grain yield, NUE and agronomic characters in open pollinated maize varieties and their $F_{1}$ hybrids as affected by $N$ fertilizer rates in 2005 and 2006 at llorin, Nigeria.

\begin{tabular}{|c|c|c|c|c|c|c|c|}
\hline Treatment & $\begin{array}{l}\text { Grain Yield } \\
\text { (t ha-1) }\end{array}$ & NUE & $\begin{array}{c}\text { Maize } \\
\text { establishment } \\
\text { count (EPC) }\end{array}$ & $\begin{array}{c}\text { Days to } 50 \% \\
\text { tasselling (TS) }\end{array}$ & $\begin{array}{l}\text { Days to } 50 \% \\
\text { silking (SK) }\end{array}$ & $\begin{array}{l}\text { Plant height } \\
(\mathrm{cm})\end{array}$ & $\begin{array}{l}\text { Ear height } \\
\text { (cm) }\end{array}$ \\
\hline \multicolumn{8}{|c|}{ Open pollinated varieties } \\
\hline $\begin{array}{l}\text { Year } \\
2005 \\
2006 \\
\text { LSD } \alpha 0.05 \\
\text { N Levels (ka N ha-1) }\end{array}$ & $\begin{array}{c}2.42 \\
2.10 \\
0.08^{\star \star}\end{array}$ & $\begin{array}{c}1.82 \\
1.06 \\
0.66^{* \star}\end{array}$ & $\begin{array}{c}39 \\
50 \\
0.76^{\star \star}\end{array}$ & $\begin{array}{c}52 \\
50 \\
0.75^{\star \star}\end{array}$ & $\begin{array}{c}53 \\
51 \\
0.85^{*}\end{array}$ & $\begin{array}{c}129 \\
113 \\
3.42^{*}\end{array}$ & $\begin{array}{c}44 \\
40 \\
2.81)\end{array}$ \\
\hline $\begin{array}{l}0 \\
45 \\
90 \\
\text { LSD } \alpha 0.05 \\
\end{array}$ & $\begin{array}{l}0.89 \\
2.18 \\
2.61 \\
0.67^{*}\end{array}$ & $\begin{array}{l}1.00 \\
2.07 \\
2.45 \\
0.45^{*} \\
\end{array}$ & $\begin{array}{l}36 \\
38 \\
37 \\
\text { ns }\end{array}$ & $\begin{array}{c}54 \\
52 \\
51 \\
0.45^{\star} \\
\end{array}$ & $\begin{array}{c}56 \\
53 \\
52 \\
0.91^{*} \\
\end{array}$ & $\begin{array}{c}101 \\
121 \\
129 \\
3.54^{*}\end{array}$ & $\begin{array}{c}35 \\
37 \\
40 \\
2.75^{*}\end{array}$ \\
\hline \multicolumn{8}{|c|}{$F_{1}$ Hybrids } \\
\hline $\begin{array}{l}\text { Year } \\
2005 \\
2006 \\
\text { LSD } \alpha 0.05 \\
\text { N Levels (kg N ha-1) }\end{array}$ & $\begin{array}{c}3.71 \\
3.70 \\
\text { ns }\end{array}$ & $\begin{array}{c}2.57 \\
2.51 \\
\mathrm{~ns}\end{array}$ & $\begin{array}{c}37 \\
33 \\
0.43^{*}\end{array}$ & $\begin{array}{c}53 \\
50 \\
0.36^{*}\end{array}$ & $\begin{array}{c}54 \\
51 \\
0.97^{\star}\end{array}$ & $\begin{array}{c}129 \\
118 \\
3.28^{\star}\end{array}$ & $\begin{array}{c}44 \\
40 \\
2.81^{*}\end{array}$ \\
\hline $\begin{array}{l}0 \\
45 \\
90 \\
\text { LSD } \alpha 0.05\end{array}$ & $\begin{array}{l}1.35 \\
2.68 \\
3.30 \\
0.98^{*}\end{array}$ & $\begin{array}{l}1.0 \\
2.14 \\
2.71 \\
0.51^{*}\end{array}$ & $\begin{array}{l}36 \\
37 \\
36 \\
\text { ns }\end{array}$ & $\begin{array}{c}54 \\
51 \\
50 \\
0.38^{*} \\
\end{array}$ & $\begin{array}{c}56 \\
54 \\
52 \\
0.96^{*}\end{array}$ & $\begin{array}{c}110 \\
122 \\
130 \\
3.11^{*}\end{array}$ & $\begin{array}{r}39 \\
40 \\
41 \\
2.61^{*}\end{array}$ \\
\hline
\end{tabular}

Table 4. Interactive effects of year $x$ nitrogen for grain yield and NUE in open pollinated varieties and their selected $F_{1}$ hybrids in 2005 and 2006 at llorin, Nigeria.

\begin{tabular}{|c|c|c|c|c|}
\hline \multirow{2}{*}{$\begin{array}{c}\text { Treatment } \\
\left(\mathrm{N} \text { Levels }\left(\mathrm{kg} \mathrm{N}^{-1}\right)\right.\end{array}$} & \multicolumn{2}{|c|}{ Open pollinated varieties } & \multicolumn{2}{|c|}{$F_{1}$ hybrids grain yield $\left(t^{2} a^{-1}\right)$} \\
\hline & 2005 & 2006 & 2005 & 2006 \\
\hline 0 & 1.09 & 0.88 & 1.35 & 1.34 \\
\hline 45 & 2.23 & 2.13 & 2.71 & 2.65 \\
\hline 90 & 2.68 & 2.54 & 3.56 & 2.45 \\
\hline LSD $\alpha 0.05$ & \multicolumn{2}{|c|}{$0.18^{\star *}$} & \multicolumn{2}{|c|}{$0.12^{\star *}$} \\
\hline \multicolumn{5}{|l|}{ NUE } \\
\hline 0 & 1.00 & 1.00 & 1.00 & 1.00 \\
\hline 45 & 2.12 & 2.01 & 2.15 & 2.13 \\
\hline 90 & 2.64 & 2.35 & 2.74 & 2.68 \\
\hline LSD $\alpha 0.05$ & \multicolumn{2}{|c|}{$0.65^{*}$} & \multicolumn{2}{|c|}{$0.39 *$} \\
\hline
\end{tabular}


Table 5. Genotypic means for maize grain yield, NUE and agronomic parameters in 10 open pollinated varieties and their selected $F_{1}$ hybrids in 2005 and 2006 at llorin, Nigeria.

\begin{tabular}{|c|c|c|c|c|c|c|c|}
\hline Genotype & $\begin{array}{l}\text { Grain Yield } \\
\quad\left(\mathrm{t} \mathrm{ha}^{-1}\right)\end{array}$ & NUE & $\begin{array}{c}\text { Maize } \\
\text { establishment } \\
\text { count (EPC) }\end{array}$ & $\begin{array}{c}\text { Days to } 50 \% \\
\text { tasselling } \\
\text { (TS) }\end{array}$ & $\begin{array}{c}\text { Days to } \\
50 \% \text { silking } \\
\text { (SK) }\end{array}$ & $\begin{array}{c}\text { Plant } \\
\text { height } \\
(\mathrm{cm}) \\
\end{array}$ & $\begin{array}{c}\text { Ear } \\
\text { height } \\
(\mathrm{cm})\end{array}$ \\
\hline \multicolumn{8}{|l|}{ Open pollinated varieties } \\
\hline Acr 90 Pool 16-Dt & 2.33 & 2.34 & 35 & 51 & 53 & 124 & 44 \\
\hline Tze Comp 4-Dmr Srbc2 & 2.29 & 1.16 & 38 & 50 & 54 & 122 & 35 \\
\hline Tze Comp4 C2 & 2.24 & 1.53 & 34 & 51 & 53 & 114 & 41 \\
\hline Acr 97 Tze Comp3 C4 & 2.21 & 1.24 & 37 & 51 & 54 & 114 & 42 \\
\hline Hei 97 Tze Comp3 C4 & 2.18 & 1.34 & 39 & 50 & 53 & 114 & 39 \\
\hline Acr 94 Tze Comp5 & 2.24 & 1.33 & 37 & 51 & 54 & 118 & 38 \\
\hline Tze Comp3 Dt & 2.38 & 2.28 & 40 & 49 & 53 & 135 & 53 \\
\hline Tze Comp3 C2 & 2.22 & 1.34 & 37 & 51 & 53 & 117 & 42 \\
\hline Ak 95 Dmr-Esrw & 2.27 & 1.56 & 36 & 51 & 54 & 122 & 44 \\
\hline Tze Msr-W & 2,24 & 1.13 & 39 & 50 & 54 & 128 & 41 \\
\hline LSD a 005 & $0.14^{*}$ & $0.34^{*}$ & $0.45^{*}$ & $0.87^{*}$ & $0.56^{*}$ & $6.04^{* *}$ & $4.42^{* *}$ \\
\hline \multicolumn{8}{|l|}{$F_{1}$ Hybrids } \\
\hline Acr 94 Tze Comp5 x Tze Comp4 C2 & 3.46 & 1.90 & 35 & 50 & 52 & 137 & 45 \\
\hline Acr 90 Pool 16-Dt x Tze Comp3 C2 & 3.48 & 1.46 & 38 & 50 & 53 & 129 & 51 \\
\hline Acr 97 Tze Comp3 C4 x Tze Comp3 Dt & 3.34 & 1.28 & 34 & 51 & 54 & 128 & 52 \\
\hline Acr 90 Pool 16-Dt x Ak 95 Dmr-Esrw & 3.48 & 1,98 & 37 & 49 & 53 & 137 & 49 \\
\hline Tze Comp3 Dt x Ak 95 Dmr-Esrw & 3.43 & 1.51 & 39 & 50 & 53 & 129 & 44 \\
\hline Tze Comp 4-Dmr Srbc2 x Ak 95 Dmr-Esrw & 3.38 & 1.36 & 37 & 51 & 54 & 135 & 40 \\
\hline Ak 95 Dmr-Esrw x Tze Msr-W & 3.44 & 1.81 & 40 & 49 & 53 & 128 & 43 \\
\hline Tze Comp3 Dt x Tze Comp3 C2 & 3.36 & 1.56 & 37 & 50 & 54 & 134 & 50 \\
\hline Acr 94 Tze Comp5 x Tze Comp3 Dt & 3.34 & 1.48 & 36 & 50 & 53 & 126 & 53 \\
\hline Acr 90 Pool 16-Dt x Tze Comp3 Dt & 3.48 & 1.90 & 39 & 49 & 52 & 128 & 52 \\
\hline Acr 94 Tze Comp5 x Tze Msr-W & 3.38 & 1.46 & 35 & 50 & 52 & 127 & 49 \\
\hline Tze Comp 4-Dmr Srbc2 x Tze Msr-W & 3.43 & 1.58 & 38 & 51 & 53 & 129 & 44 \\
\hline Tze Comp4 C2 x Tze Comp3 Dt & 3.48 & 1,98 & 34 & 50 & 52 & 135 & 40 \\
\hline Tze Comp4 C2 x Tze Comp3 C2 & 3.43 & 1.98 & 36 & 51 & 54 & 128 & 43 \\
\hline LSD a 005 & $0.17^{*}$ & $0.56^{*}$ & $0.67^{*}$ & $0.89^{*}$ & $0.66^{*}$ & $5.98^{* *}$ & $4.30^{* *}$ \\
\hline
\end{tabular}

*, **; Significant $F$ test at 0.05 and 0.01 levels of probability respectively

Effect of cropping season on open pollinated varieties and their $F_{1}$ hybrids performance: The rainfall in 2006 growing season was more favourable for the expression of all studied characters among the genotypes than 2005 (Fig. 1). Each of the cropping seasons had significant effect on all the characters measured in the open pollinated varieties and hybrids, except for nitrogen use efficiency (NUE) and grain yield in the hybrids (Table 3). The plants were significantly taller, with higher ear placement, subsequently higher grain yield, more efficient utilization of $\mathrm{N}$ and higher anthesis-silking interval. However, expressions of these traits in the hybrids were relatively higher than the OPVs.

Effect of $N$ fertilizer rates on grain yield, NUE and other agronomic characters: Varying the N-fertilizer rate significantly affected the expression of the characters in both OPVs and hybrids (Table 3). Grain yield increased with increasing in N-dosage in the OPVs and hybrids but was higher in the hybrids relative to OPVs. The NUE of hybrids and OPVs increased significantly by increasing the N-level from 0 to $45 \mathrm{~kg} \mathrm{~N}^{-1}$. Though the NUE showed consistent trend in both groups from 45 to $90 \mathrm{~kg} \mathrm{~N}^{-1}$, the increament was significant only for hybrids. The grain yield increased significantly from 0.89 to $2.18 \mathrm{t}$ ha-1 and 1.35 to $2.68 \mathrm{t}$ ha-1 for OPVs and hybrids respectively by increasing $\mathrm{N}$-application from 0 to $45 \mathrm{~kg} \mathrm{~N} \mathrm{ha}^{-1}$. The total increase in grain yield observed was $1.72 \mathrm{t} \mathrm{ha-}{ }^{-1}$ and $1.95 \mathrm{t} \mathrm{ha}^{-1}$ for OPVs and hybrids respectively on application of 90 $\mathrm{kg} \mathrm{ha-}{ }^{-1}$ over no $\mathrm{N}$-application. However, the increase in grain yield was not statistically significant in either case. Days to $50 \%$ tasselling and silking decreased with increasing $\mathrm{N}$ application rate, while plant and ear heights increased significantly with increasing $\mathrm{N}$ application rate in both groups. 
Interactive effects of year $x$ nitrogen on grain yield and NUE: The first order interaction of year $\mathrm{x}$ nitrogen was significant for both grain yield and NUE in the OPVs and hybrids (Table 4). Significantly, higher grain yield was obtained at $90 \mathrm{~kg} \mathrm{~N} \mathrm{ha}^{-1}$ in 2005 than 2006 in both genotypes. Grain yield increased significantly at every $\mathrm{N}$ level between 0 and $90 \mathrm{~kg} \mathrm{~N}^{-1}$ with a difference of 1.59 and $1.66 \mathrm{tha}^{-1}$ in OPVs and 2.22 and 2.11 $\mathrm{t} \mathrm{ha} \mathrm{a}^{-1}$ in the hybrids at the first and second years respectively. However, NUE was best at $90 \mathrm{~kg} \mathrm{~N} \mathrm{ha}^{-1}$ regardless of the growing season among the genotypes.

Genotypic performance for grain yield, NUE and other agronomic characters: The hybrids differed significantly for all the traits and showed superiority with respect to grain yield than their respective OPVs (Table 5). Although, there was no significant genotype $x \mathrm{~N}$ fertilizer effects for grain yield and NUE in this study, but most of the hybrids appeared to exhibit capacity for utilizing $\mathrm{N}$ better than their respective parents. Two drought tolerant varieties (Acr 90 Pool 16-Dt and Tze Comp3 Dt) not only had the highest grain yield and NUE among OPVs, but also specifically combined well with each other and some cultivars. While Acr 90 Pool 16-Dt favourable combined with Tze Comp3 Dt, Tze Comp3 C2 and Ak 95 Dmr-Esrw for these characters, var. Tze Comp3 Dt combined well with Tze Comp4 C2. The genotypes were also taller with higher ear placement, increase in days to $50 \%$ tasselling and silking. However, correlation of grain with other traits among the parents and hybrids showed that grain yield correlated positively and significantly with growth characteristics measured except days to $50 \%$ silking (Table 6). NUE correlated positively and significantly with all agronomic characters except days to $50 \%$ silking in the OPVs.

Table 6. Simple linear correlation coefficient of grain yield, NUE and agronomic parameters in 10 open pollinated maize varieties and 45 $F_{1}$ hybrids in 2005 and 2006 at llorin, Nigeria.

\begin{tabular}{|c|c|c|c|c|}
\hline Parameters & \multicolumn{2}{|c|}{ Open pollinated varieties } & \multicolumn{2}{|c|}{ F 1 Hybrids } \\
\hline & Grain Yield $\left(\mathrm{t} \mathrm{ha}^{-1}\right)$ & NUE & Grain Yield (t ha-1) & NUE \\
\hline Maize establishment count & $0.320^{* \star}$ & $0.315^{* *}$ & $0.411^{* \star}$ & $0.325^{* *}$ \\
\hline Days to $50 \%$ tasselling & $0.235^{\star \star}$ & $0.261^{* *}$ & $0.387^{\star \star}$ & $0.341^{* *}$ \\
\hline Days to $50 \%$ silking & 0.042 & -0.016 & 0.009 & -0.076 \\
\hline Plant height & $0.147^{* *}$ & $0.140^{* *}$ & $0.345^{\star \star}$ & 0.134 \\
\hline Ear height & $0.235^{\star *}$ & $0.125^{*}$ & $0.140^{*}$ & $0.110^{*}$ \\
\hline NUE & $0.521^{* *}$ & - & $0.242^{* *}$ & \\
\hline
\end{tabular}

Table 7. Estimates of genotypic and phenotypic variances, coefficients of genetic variability and genetic advance in agronomic characters among open pollinated maize varieties and their $F_{1}$ hybrids as affected by $N$ fertilizer rates in 2005 and 2006 at llorin, Nigeria.

\begin{tabular}{lccccc}
\hline Character & $\delta^{2} \mathrm{~g}$ & $\delta^{2} \mathrm{p}$ & $\mathrm{GCV}$ & $\mathrm{PCV}$ & $\mathrm{GA}(\%)$ \\
\hline Establishment count & 3.6 & 17.4 & 52.4 & 118.8 & 12.2 \\
Days to 50\% tasselling & 32.7 & 156.3 & 74.1 & 159.8 & 27.0 \\
Days to 50\% silking & 10.5 & 317.2 & 16.8 & 254.6 & 11.9 \\
Plant height & 608.6 & 1062.5 & 129.6 & 517.5 & 1162.8 \\
Ear height & 121.4 & 1054.6 & 128.7 & 213.6 & 175.8 \\
Grain yield & 3.2 & 3.5 & 71.6 & 75.3 & 95.0 \\
\hline$\delta^{2} \mathrm{~g}=$ Genotypic variance, $\delta^{2} \mathrm{p}=$ Phenotypic variance, GCV= Genotypic coefficient of variation, PCV= Phenotypic coefficient of variation, GA= Genetic advance
\end{tabular}

Genetic gains and variances for grain yield and other agronomic characters: Estimates of genotypic and phenotypic variances as well as coefficients of genotypic and phenotypic variations, and genetic advance are presented in Table 7. The value for genotypic variances ranged from 3.2 for grain yield to 608.6 for plant height, while the phenotypic variances ranged from 17.4 for establishment count to 1062.5 for plant height. The coefficients of variations also showed that the phenotypic coefficients of variations (PCV) were higher than the genotypic coefficients of variations (GCV) for all the parameters measured. Plant height had the highest GCV (129.6) and PCV (252.9). Similarly, highest genetic gain of $1162.8 \%$ was recorded for plant height and the least genetic gain of $11.9 \%$ for days to $50 \%$ silking. 


\section{Discussion}

The release of improved stress-tolerant maize varieties and hybrids has sparked optimism for increased maize productivity in Nigeria. These cultivars have the potential to provide farmers with opportunities to overcome the challenges to maize production. However, efficiency of plants in making use of soil nutrients within their environment is expected to be optimal with adequate soil moisture regime. Although rainfall distribution throughout the duration of this study appears favourable for crop growth and expression of studied traits in both OPVs and the $F_{1}$ hybrids, the second year precipitation was more beneficial (Fig. 1). However, the results from these experiments showed that hybrid maize efficiently utilized nitrogen better than OPVs as per earlier reports in Nigeria (Akintoye et al. 1999, Kogbe and Adediran 2003). In both years, hybrids gave higher yield than the OPVs even at low soil $\mathrm{N}$ status. Consequently, maize yield increased with increasing nitrogen availability and this is in agreement with previous report of Kogbe and Adediran (2003). All the genotypes responded adequately to $\mathrm{N}$ application even as low as $45 \mathrm{~kg} \mathrm{~N} \mathrm{ha}^{-1}$. Cultivars identified as less responsive to applied $\mathrm{N}$ sometimes perform better at low $\mathrm{N}$ than do $\mathrm{N}$-responsive hybrids or OPVs (Pollmer et al. 1979). The low $\mathrm{N}$ tolerant cultivars are superior in the utilization of available $\mathrm{N}$, either due to enhanced uptake capacity or because of more efficient use of absorbed $\mathrm{N}$ in grain production (Lafitte and Edmeades 1994, Jafartayari et al. 2012). However, number of days recorded in 2006 especially at anthesis was less than that recorded in 2005 , which facilitated optimum utilization of available soil nutrients. This probably explains the higher grain yield and superiority in $\mathrm{N}$ utilization observed in the OPVs in 2005 relative to 2006 (Table 3) and also the significant year $\mathrm{x}$ nitrogen interaction for this character in both parents and hybrids (Table 4). Values for NUE, plant and ear heights were higher in 2005 compared to 2006 in both OPVs and hybrids. This observation tends to underscore the importance of moisture availability especially at anthesis in the accumulation of photo assimilates as well as its translocation for grain production in maize.

Grain yield and NUE increased in a consistent manner with increasing $\mathrm{N}$ rate in both parents and hybrids (Table 3). This is in line with previous reports (McCullough et al. 1994, Uhart and Andrade 1995) that variation in $\mathrm{N}$ supply affects both growth and development of maize plants. The capacity to utilize $\mathrm{N}$ as measured by NUE and consequently grain yield in this study was optimum at $45 \mathrm{~kg} \mathrm{~N} \mathrm{ha}^{-1}$ in both varieties and hybrids which were similar to the result obtained by Elemo (1997) in the northern Guinea savannah of Nigeria in which the author reported a yield increase of $200 \%$ over the control at $40 \mathrm{~kg} \mathrm{~N} \mathrm{ha}^{-1}$ in two maize varieties of different maturity period. This result is also in support with earlier findings (Lafitte and Banziger 1994, Namakka et al. 2008, Adekayode and Ogunkoya 2010, Gagnon and Ziadi 2010, Jafartayari et al. 2012) on increase in grain yield and NUE at low N levels. Kogbe and Adediran (2003) similarly observed that maize varieties responded adequately well to nitrogen application in the southern Guinea savanna of Nigeria and gave over $3 \mathrm{tha}^{-1}$ grain yield by applying as low as $50 \mathrm{~kg} \mathrm{~N} \mathrm{ha}^{-1}$. They suggested that this could erase the fear that without high $\mathrm{N}$ input, hybrid maize would not give some appreciable returns. However, there was no significant genotype $\mathrm{x} \mathrm{N}$ fertilizer effects for grain yield and NUE in this study with similar to the finding of Ma et al. (1999), but contradicts- the findings of Bertin and Gallais (2000) who observed that maize differed in their capacity for $\mathrm{N}$ uptake, assimilation and redistribution of $\mathrm{N}$ from vegetative to reproductive tissues. The fact that the OPVs used in this study are of the same maturing group may be responsible for the difference in the two results.

High phenotypic coefficients of variations values observed in both OPVs and hybrids may indicate significant year $\mathrm{x}$ nitrogen interactions for all the characters measured. This therefore affirms that the populations used in this study showed greater range of genetic variability under different $\mathrm{N}$ fertilizer rates. Genetic differences have been observed among maize genotypes (inbred lines, hybrids and OPVs) in response to $\mathrm{N}$ fertilizer application and efficient utilization of absorbed $\mathrm{N}$ for grain yield (Banziger et al. 1999, Kling et al. 1997, Abdel Rahman et al. 2002). The high genetic gain of plant and ear heights may indicate that these traits could be selected for genetic improvement of maize under different $\mathrm{N}$ regimes, as earlier suggested (Castleberry et al. 
1984, Yusuf 2010). Plant height and days to $50 \%$ silking that had highest and lowest genetic gains respectively signify broader genetic base for plant height and narrower genetic base for days to $50 \%$ silking among the genotypes. Though low genetic gain was recorded for days to $50 \%$ silking and days for establishment count, there is a significant variability in these traits and hence may also be useful in maize breeding programme. Grain yield correlated positively with most of the parameters measured and this has also been reported by Tenaw (2000).

\section{Conclusion}

Two drought tolerant varieties (Acr 90 Pool 16-Dt and Tze Comp3 Dt) that combined well with specific cultivars for grain yield and NUE probably have gene pools for low N-tolerance. Therefore, these varieties can further be tried under farmers' growing conditions or could be hybridized for development of inbred lines in the development of $\mathrm{N}$ stress-tolerance varieties for cultivation in the SGS ecology.

\section{References}

Abdel-Rahman AM, Magboul EL, Abdelatief EN. 2002. Effects of sowing date and cultivar on the yield and yield components of maize in northern Sudan.. In: Friesen DK, Palmer AFE (ed.) Integrated approaches to higher maize productivity in the new millennium: Proc 7th Eastern Southern Africa Regional Maize Conf, Nairobi, Kenya. 5-11 Feb. 2001. CIMMYT and Kenya Agric Res Inst, Nairobi, pp. 295-298.

Adekayode FO, Ogunkoya MO. 2010. Effect of quantity and placement distances of inorganic 15-15-15 fertilizer in improving soil fertility status and the performance and yield of maize in a tropical rain forest zone of Nigeria. J Soil Sci Environ Manag 1(7), 155-163.

Akintoye HA, Kling JG, Lucas EO. 1999. N use efficiency of single, double and synthetic maize lines grown at $4 \mathrm{~N}$ levels in three ecological zones of West Africa. Field Crop Res 60, 189-199. http://dx.doi.org/10.1016/S0378-4290(98)00122-1

Banziger M, Lafitte HR, Edemeades GO, Betran FJ, Berk DL, Elings A. 1999. Recent advances in breeding for tolerance to low nitrogen in tropical maize, pp. 21-34. In. Badu-Apraku B, Fakorede MAB, Ouedraogo M, Quin FM. (eds). Proceedings of a Regional maize workshop, 21-25 April, 1997, IITA Cotonou, Benin Republic.

Bello OB, Abdulmaliq SY, Afolabi MS, Ige SA. 2010. Correlation and path coefficient analysis of yield and agronomic characters among open pollinated maize varieties and their $\mathrm{F}_{1}$ hybrids in a diallel cross. Afr J Biotechnol 9(18), 2633-2639.

Bello OB. 2008. Combining ability for maize grain yield in striga endemic and non-endemic environments of the southern Guinea savanna, Nigeria. Ph.D. Thesis. The University of llorin, Ilorin, Nigeria. pp 86.

Bertin P, Gallais A. 2000. Physiological and genetic basis of nitrogen use efficiency in maize. I. Agrophysiological results. Maydica 45, 53-66.

Bray RH, Kurtz LT. 1945. Determination of total organic and available forms of phosphorus in soils. Soil Sci 59, $39-45$. http://dx.doi.org/10.1097/00010694-194501000-00006

Bremner JM. 1965. Total nitrogen. I methods of soil analysis. II chemical and microbiological properties. In: Black CA, Evans DD, White JL, Ensminger LE, Clerk FE, Dinauer RC (eds) Agronomy Monograph, 9, American Society of Agronomy Madison, Wisconson USA. pp 26.

Carsky RJ, Iwuafor ENO. 1999. Contribution of soil fertility research and maintenance to improved maize production and productivity in sub-Saharan Africa. In. B. Badu-Apraku et al. (eds). Strategy for sustainable maize production in West and Central Africa. Proc.Regional Maize Workshop, IITA-Cotonou, Benin Republic. 21-25 Apr. 1997. West and Central Africa Collaborative Maize Res. Network, Int. Inst. of Tropical Agric., Ibadan, Nigeria.

Castleberry RM, Crum CW, Krull CF. 1984. Genetic yield improvement of U.S. maize cultivars under varying fertility and climatic environments. Crop Sci 24, 33-36. http://dx.doi.org/10.2135/cropsci1984.0011183X002400010008x

Elemo KA. 1997. Extra-early and early maize varieties as affected by rate and time of nitrogen fertilization. In: Contribution of food selfsufficiency: Maize research and development in West and Central Africa. Proceedings of a regional maize workshop, IITA, Cotonou, Benin Republic. Pp. 241-246.

Fakorede MAB, Badu-Apraku B, Coulibaly O, Fajemisin JM. 2001. Impact challenges and prospect of maize research and development in west and central Africa. Proceedings of a regional maize workshop, 4-7 May, 1999, WECAMAN/ITA Cotonou, Benin Republic. pp. 45.

Gagnon B, Ziadi N. 2010. Grain corn and soil nitrogen responses to side-dress nitrogen sources and applications. Agron J 102, 10141022. $h$ ttp://dx.doi.org/10.2134/agronj2010.0011

Genstat. 1995. Genstat 5 release 3.2. Reference manual supplement. Clarendon Press, Oxford, U.K.

Gomez AG, Gomez AA. 1984. Statistical procedures for Agricultural research. IRRI Book, 2nd edition, John Wiley \& Sons Inc. N. Y. 
IITA (International Institute of Tropical Agriculture) 1989. Automated and semi-automated methods for soil and plant analysis. Manual series No. 7, IITA, pp. 726, Ibadan, Nigeria.

Jafartayari D, Naderidarbahghsahi M, Javanmard H. 2012. Source limitation, nitrogen topdressing and seed yield relationship in different cultivars of maize (Zea mays L.). Int J Agri Sci 2(5), 408-413.

Juo ASR, Mano A. 1996. Chemical dynamics in slash-and-burn Agriculture. Agri Ecosys Environ 58, 9-18. http://dx.doi.org/10.1016/0167-8809(95)00656-7

Juo ASR. 1979. Methods of Plant and Soil Analysis. Manual Series No.1. International institute for Tropical Agriculuture, Ibadan, Nigeria, $65 \mathrm{pp}$.

Kling JG, Heuberger HT, Oikeh SO, Akintoye HA, Horst WJ. 1997. Potential for developing nitrogen-use efficient maize for low-input Agricultural systems in the moist savannas of Africa. pp. 490-501. In: Edemeades GO, Banziger M, Mickelson HR, Pena-valdiva CB (eds). Developing drought and low-N tolerant maize. Proceedings of a symposium. March, 25-29, 1996, CIMMYT, E. I. Batan, Mexico, Mexico D. F.

Kogbe JOS, Adediran JA. 2003. Influence of nitrogen, phosphorus and potassium application on the yield of maize in the savanna zone of Nigeria. Afr J Biotechnol 2 (10), 345-349.

Lafitte HR, Banziger M. 1994. Strategies that improve maize varietal performance under low N; Progress due to selection. pp. 57-63. In. Jewell DC, Waddington SH, Ranson JK, Pixley KV (eds). Maize research for stress environment. Proc. of the fourth Eastern and Southern Africa regional maize conference, $28^{\text {th }}$ March -1 st April, 1994, Harare, Zimbabwe.

Lafitte HR, Edmeades GO. 1994. Improvements of tolerance to low soil nitrogen in tropical maize. I Selection criteria. Field Crop Res 39, 1-14. http://dx.doi.org/10.1016/0378-4290(94)90066-3

Ma BL, Lianne MD, Edward GG. 1999. Soil nitrogen amendment effects on nitrogen uptake and grain yield of maize. Agron J 91, 650656. http://dx.doi.org/10.2134/agronj1999.914650x

McCullough DE, Girardin P, Mihajlovic M, Aguilera A, Tollenaar M. 1994. Influence of N supply on development and dry matter accumulation of an old and new maize hybrid. Can J Plant Sci 74, 471-477. http://dx.doi.org/10.4141/cjps94-087

Mode CJ, Robinson HF. 1959. Pleiotropism and the genetic variance and covariance. Biometrics 15, 518-537. http://dx.doi.org/10.2307/2527650

Namakka Al, Abubakar U, Sadik Al, Sharifai Al, Hassas AH. 2008. Effect of sowing date and nitrogen level on yield and yield components of two extra early maize varieties (Zea mays L.) in Sudan savanna of Nigeria. ARPN J Agri Biol Sci 3(2), 46-51.

Nelson DW, Somers LE. 1992. Total carbon, total organic carbon and organic matter. pp. 539-580. In: Miller et al. (ed). Methods of soil analysis, Part 2, $2^{\text {nd }}$ ed, Agronomy Monograph, 27, ASA, Madison, W. I.

Pollmer WG, Eberhard D, Klein D, Dhillon BS. 1979. Genetic control of nitrogen uptake and translocation in maize. Crop Sci 19, 82-86. http://dx.doi.org/10.2135/cropsci1979.0011183X001900010019x

Sanginga N, Okogun JA, Vanlauwe B, Diels J, Carsky RJ, Dashiell K. 2001. Nitrogen contribution of promiscuous soybeans in maize based cropping systems. SSSA Special Publication 58, Madison, USA. pp. 157-177.

Smith ME, Miles CA, Beem JV. 1994. Genetic improvement of maize for nitrogen use efficiency in eastern and southern Africa. In: Jewell DC, Waddington SH, Ranson JK, Pixley KV (eds). Maize research for stress environment. Proc. of the fourth Eastern and Southern Africa Regional Maize Conference, 28/3-1/4 1994, Harare, Zimbabwe. Pp. 39-43.

Tenaw W. 2000. Effect of nitrogen fertilizer rates and plant density on grain yield of maize. Afr Crop Sci J 8(3) 273-282.

Uhart SA, Andrade FH. 1995. Nitrogen deficiency in maize: I. Effects on crop growth, development, dry matter partitioning, and kernel set. Crop Sci 35, 1376-1383. http://dx.doi.org/10.2135/cropsci1995.0011183X003500050020x

Undie UL, Uwah DF, Attoe EE. 2012. Growth and development of late season maize/soybean intercropping in response to nitrogen and crop arrangement in the forest agro-ecology of South Southern Nigeria. Int $J$ Agric Res 7 (1), 1-16. http://dx.doi.org/10.3923/ijar.2012.1.16

Yusuf AA, Iwuafor ENO, Abaidoo RC, Olufajo OO, Sanginga N. 2009. Effect of crop rotation and nitrogen fertilization on yield and nitrogen efficiency in maize in the northern Guinea savanna of Nigeria, Afr J Agric Res 4 (10), 913-921.

Yusuf AA, Janssen BH, Chude VO. 2003. Substitution rates of N, $\mathrm{P}$ and $\mathrm{K}$ in farmyard manure on an Alfisol in northern Guinea savanna of Nigeria. J Agric Environ Int Dev 97(12), 93-105.

Yusuf M. 2010. Genetic variability and correlation in single cross hybrids of quality protein maize (Zea Mays L.). Afr J Food Agric Nutr Dev 10(2), 2166-2175. 